\title{
BELAJAR GERAK DAN MATEMATIKA DASAR MELALUI PENDEKATAN PEMBELAJARAN TERPADU DI SEKOLAH DASAR
}

\author{
Nina Sutresna \\ FPOK Universitas Pendidikan Indonesia \\ email: nina.sutresna@gmail.com
}

\begin{abstract}
Abstrak: Tujuan penelitian mengkaji perbedaan pengaruh antara pendekatan pembelajaran terpadu dan pembelajaran konvensional terhadap peningkatan kemampuan motorik dasar dan mengetahui pengaruh kemampuan awal terhadap kedua pendekatan tersebut. Taraf kemampuan awal dibagi menjadi kemampuan matematika dasar tinggi dan rendah. Penelitian dilakukan di SDN Panyileukan I Bandung Jawa Barat. Penelitian dilakukan dengan metode eksperimen dengan sampel sebanyak 40 orang. Tes kemampuan motorik dan matematika dasar dipakai sebagai alat untuk mengumpulkan data. Teknik analisis memakai Anava 2x2 dengan uji lanjut Tuckey dan uji t pada taraf siginifikansi 0,05. Hasil penelitian menunjukkan bahwa secara keseluruhan hasil belajar pendekatan pembelajaran terpadu lebih baik daripada hasil belajar konvensional. Untuk kemampuan awal matematika dasar rendah pendekatan pembelajaran terpadu lebih baik dari pendekatan konvensional, sedangkan untuk kemampuan awal matematika dasar tinggi tidak terdapat perbedaan antara kedua pendekatan pembelajaran tersebut. Hasil belajar matematika pendekatan pembelajaran terpadu lebih tinggi dibandingkan pendekatan konvensional.
\end{abstract}

Kata Kunci: belajar gerak, matematika dasar, pembelajaran terpadu

\section{LEARNING MOVEMENT AND BASIC MATHEMATIC THROUGH INTEGRATED LEARNING APPROACH IN ELEMENTRY SCHOOL}

\begin{abstract}
The purpose of the researches to findout the differences of effect between conventional learning and integrated learning approuch on learning performance of physical education of elementary school students. In addition the research is also aimed at finding out the effect of entry behavior on both approuches. The entry behavior requarements are classified into high and low basic mathematic entry behavior. This research was conducted at SDN Panyileukan I Bandung, West Java addopting $2 \times 2$ factorial design experimental 40 student as sample. Basic motoric and basic mathematic test were used as measuring tools for data collection. Factorial variant $2 \times 2$ analysis, Tuckey analysis and tanaysis were employed at a significant level at 0,05 . The research concludes that in general integrated learnig approuch for basic motor ability is higher than conventional learning approuch, In case of high entry behavior performance of integrated learing approuch is higher than conventional learning approach, In case of lowentry behavior however there is no differences in performance between integrated learing approuch than conventional learning approuch. For mathematic in general integrated learning approach is higher than conventional learning approuch.
\end{abstract}

\section{Keywordss: learning movement, basic mathematic, integrated learning}

\section{PENDAHULUAN}

Proses pembelajaran gerak pada tingkat dasar merupakan media yang strategis untuk membantu pertumbuhan dan perkembangan anak. Salah satu tugas pengajar adalah memberikan peluang dengan efektif sehingga apa yang diperlukan peserta didik terpenuhi. Peluang tersebut dapat dicapai bila tercipta hubungan antara guru dan murid yang bersifat kritis interaktif yang memberikan arah untuk tumbuhnya kreatifitas, berpikir kritis dan percaya diri. Peran guru sebagai mitra yang membantu meciptakan peluang-peluang untuk terjadinya proses belajar pada diri perserta didik, akan menggiring pada persyaratan professional dan kemampuan profesional yang mau tidak mau harus memadai, sebab bila tidak, tugas yang dibebankan kepada guru tidak mungkin 
dikerjakan dengan optimal. Salah satu tugas guru adalah memiliki pemahaman tentang pendekatan pembelajaran yang mengindahkan pertumbuhan dan perkembangan peserta didik.

Konsep pendekatan pembelajaran diklasifikasikan dalam dua pendekatan, yaitu pendekatan yang berpusat pada guru (teacher centred approaches) dan pendekatan yang berpusat pada siswa (student centred approaches). Pendekatan yang berpusat pada guru menurunkan strategi pembelajaran langsung (direct instruction), pembelajaran deduktif atau pembelajaran ekspositori. Pendekatan yang berpusat pada siswa menurunkan strategi pembelajaran inkuiri dan diskoveri serta pembelajaran induktif (Rusman, 2011:132)

Pemilihan suatu pendekatan pembelajaran tidak hanya menuntut kualitas pembelajaran menjadi lebih baik, seperti keterlibatan siswa dalam proses pembelajaran, adanya pola hubungan yang baik antara guru dengan siswa dalam suasana yang menyenangkan, tetapi berkaitan juga dengan aspek-aspek yang akan dikembangkan seperti aspek kognitif, afektif maupun psikomotor. Proses pembelajaran dan pelatihan merupakan kegiatan yang mendukung dan mendorong serta menjaga tercapainya tujuan. Pembelajaran merupakan proses membuat orang belajar atau memanipulasi lingkungan sehingga memberikan kemudahan orang untuk belajar. Makna pembelajaran kurang lebih sama dengan teknik atau metode instruksional, tetapi juga digunakan untuk merujuk kepada perintah guru tentang pengetahuan materi pelajaran, kemampuan untuk menafsirkan tanggapan siswa, dan kompetensi pribadi lainnya (Tinning, 2010:9).

Berdasarkan definisi tentang pendekatan dan pembelajaran tersebut, dapat ditarik makna jelas tentang pendekatan pembelajaran sesuai dengan konteks penelitian ini, pembelajaran yakni usaha atau tindakan yang dilakukan dalam mengelola aktivitas pembelajaran guna mencapai tujuan.

Sorotan terhadap makin melemahnya kualitas hasil dan proses belajar pada tingkat pendidikan dasar dan menengah menjadi bagian lain yang cukup menggelitik pendidik. Berbagai faktor penyebab telah dianalisa dan diungkapkan alternatif pemecahannya, namun Nampaknya belum memberikan dampak perubahan yang mendasar dalam mengatasi persoalan makin menurunnya mutu pendidikan dasar tersebut. Faktor penyebab penurunan mutu proses dan hasil belajar anak adalah proses pembelajaran yang terlalu 'menuntut' anak menguasai materi kurikulum yang disediakan bagi setiap tingkatan kelas. Guru dengan segala cara 'menjejali' anak untuk menguaai kurikulum yang telah ditargetkan tanpa melihat apakah materi kurikulum tersebut sesuai dengan minat dan hidup anak atau tidak. Bukan berarti penguasaan fakta tidak penting, tapi disadari atau tidak, fakta yang harus dikuasai anak makin hari makin banyak. Di sisi lain, minat, kemampuan, dan interes anak kurang diperhatikan dalam proses pembelajaran sehingga timbul perasaan pada anak bahwa belajar di sekolah merupakan suatu beban dan bukan sesuatu yang menyenangkan dirinya. Untuk dapat mengelola kegiatan belajar mengajar sehingga dapat membuahkan dampak langsung maupun dampak pengiring yang dikehendaki, guru harus mengendalikan keputusan serta tindakan mengajarnya agar sesuai dengan kedua jenis sasaran yang dimaksud.

Salah satu alternatif untuk memecahkan persoalan yang kerap terjadi dalam proses pembelajaran, memunculkan ide untuk mengembangkan proses pembelajaran yang kreatif-interaktif melalui penyajian model pendekatan pembelajaran terpadu. Pendekatan yang cukup inovatif ini diharapkan mampu menyajikan berbagai pilihan bagi siswa dan juga guru dalam pelaksanaan proses belajar-mengajar. Konsep pembelajaran terpadu tampak dalam pendidikan jasmani, terutama di kelas-kelas awal. Kian rendah kelas anak, kian nyata pendekatan terpadu. Misalnya, dalam tingkatan yang paling sederhana pendidikan jasmani dapat dikaitkan dengan matematika, bahasa, dan mata pelajaran lainnya yang relevan.

Model pendekatan yang bisa dilakukan oleh guru dalam pelaksanaan pembelajaran terpadu terdiri dari berbagai model, dimulai dari yang paling sederhana sampai yang paling kom- 
pleks. Model pendekatan yang biasa dikembangkan di Indonesia ialah connected modell model keterhubungan antarbidang studi, thematic model/model topik inti, dan intergreted modell model terpadu/proyek (Saud, 1996:5). Penelitian ini mengkaji tentang penerapan model keterhubungan antarbidang studi (the connected model), yakni mengintergretasikan materi pendidikan jasmani dengan matematika dalam proses pembelajaran penjas pada siswa SD kelas 1 dan 2. Pemilihan pelajaran matematika yang dipadukan dengan pelajaran pendidikan jasmani semata-mata berdasarkan pertimbangan bahwa materi-materi matematika sangat memungkinkan untuk dipadukan dengan materi pelajaran pendidikan jasmani. Sebagaimana kita ketahui, materi pelajaran matematika yang harus dikuasai oleh siswa kelas satu dan dua berdasarkan kurikulum cukup sulit sehingga bagi sebagian siswa pelajaran matematika tersebut menjadi pelajaran yang menakutkan dan bukan sesuatu yang menyenangkan. Oleh karena itu, perlu dicari suatu pendekatan yang lebih memudahkan siswa dalam menerima materi-materi pelajaran matematika.

Kenyataan di lapangan menunjukan, bahwa waktu pelajaran pendidikan jasmani merupakan waktu yang menyenangkan bagi siswa, terutama setelah sekian jam harus berada dalam ruangan. Kondisi demikian dapat dimanfaatkan oleh guru dengan memberikan sesuatu yang tadinya cukup 'menakutkan' menjadi sesuatu yang 'menarik', yakni 'belajar sambil bermain'.

Berkaitan dengan pendekatan pembelajaran terpadu ini, peneliti mencoba untuk mengungkapkan bagaimana pengaruh pendekatan pembelajaran terpadu terhadap hasil belajar pendidikan jasmani di sekolah dasar, baik bagi siswa yang memiliki kemampuan matematika tinggi, maupun rendah. Dengan pendekatan pembelajaran ini, pelajaran pendidikan jasmani yang diberikan pada sisiwa tidak lagi sebagai mata pelajaran yang berdiri sendiri sebagaimana yang biasa dilaksanakan oleh guru-guru penjas selama ini. Melalui pendekatan yang berbasis pada intergreted learning penyajian materi dikaitkan dengan materi matematika. Oleh sebab itu, sebagai output di akhir pelajar- an, di samping kemampuan motorik yang ingin dicapai, maka sebagai dampak pengiring, kemampuan matematika dasar turut dipertimbangkan sebagai hasil belajar.

\section{METODE}

Metode yang digunakan dalam penelitian ini adalah metode eksperimen dengan menerapkan model pembelajaran pendidikan jasmani yang dipadukan dengan materi matematika bagi siswa sekolah dasar. Penelitian eksperimen merupakan penelitian yang sistematis, logis, dan teliti di dalam melakukan kontrol terhadap kondisi. Riyanto (Zuriah, 2006:57) mengemukakan bahwa dalam melakukan eksperimen peneliti memanipulasi suatu stimulan treatment atau kondisi-kondisi eksperimental, kemudian mengobservasi pengaruh yang diakibatkan oleh adanya perlakuan atau manipulasi tersebut

Metode ini digunakan atas dasar pertimbangan bahwa sifat penelitian eksperimental yaitu mencobakan sesuatu untuk mengetahui pengaruh atau akibat dari suatu perlakuan atau treatment. Percobaan sesuatu yang dimaksud dalam penelitian ini adalah untuk mengetahui perbandingan pengaruh model pendekatan pembelajaran terpadu dengan pendekatan pembelajaran konvensional terhadap hasil pembelajaran motorik dan juga pembelajaran pengenalan matematika dasar pada siswa sekolah dasar dengan menyertakan variabel atribut yang kemampuan berhitung dasat tinggi dan rendah.

Penerapan perlakuan terhadap dua kelompok sampel mengacu pada penjelasan sebagai berikut.

"An experiment usually involves two groups of subjects, an experimental group and a control or a comparison group, .......The experimental group receives a treatment of some sort (such as a new textbook or a different method of teaching), while the control group receives no treatment (or the comparison group receives a different treatment). The control or the comparison group is crucially important in all experimental research, for it enables the researcher to determine whether the treatment has had an effect or whether one treatment is more effective than another" (Fraenkel, 2011: 266). 
Data dikumpulkan dengan teknik tes. Tes dilakukan sebanyak dua kali (pretes dan postes). Untuk memperoleh data gerak motorik dasar digunakan tes motor abilitas dengan modifikasi. Tes terdiri atas tiga item tes, yakni: (1) tes lari 30m untuk mengukur kecepatan lari; (2) tes lompat jauh tanpa awalan untuk mengukur kekuatan tungkai; dan (3) tes melempar bola sejauh mungkin untuk mengukur kekuatan lengan. Untuk mengukur kemampuan matematika dasar digunakan tes aritmatik yang mengacu pada tes Weschler Intelegency Scale for Children. Sebelum digunakan, terlebih dahulu alat tes diujicobakan dan untuk menghitung tingkat reliabilitas tes yang digunakan dicari dengan teknik tes-retes. Dari hasil uji coba tes kemampuan motorik diperoleh reliabilitas $(r=$ 0,8653 ), sedangkan untuk tes matematika dasar diperoleh reliabilitas $(r=0,7901)$.

Analisis data dilakukan dengan menggunakan Anava 2x2 dilanjutkan dengan uji Tuckey pada taraf $\alpha=0,05$. Untuk mengetahui perbedaan peningkatan hasil belajar matematika dasar antara kelompok yang diajar dengan pendekatan pembelajaran terpadu dan pendekatan pembelajaran konvensional dilakukan dengan Uji-t. Instrumen yang digunakan dalam pengumpulan data adalah tes Gerak dasar (Motor ability test) dan tes kemampuan matematika dasar.

\section{HASIL DAN PEMBAHASAN}

Data hasil belajar pendidikan jasmani yang digunakan untuk analisis, adalah total nilai kemampuan motorik yang terdiri dari nilai lari, lempar dan lompat serta peningkatan kemampuan kognitif berupa nilai matematika dasar siswa setelah mengikuti pelajaran selama 24 pertemuan. Data tersebut yang dimaksud ditunjukkan pada Tabel 1.

Hasil Belajar Motorik Dasar pendekatan Pembelajaran Terpadudan Pendekatan Konvensional pada Siswa dengan Kemampuan Matematika Dasar Tinggi

Mengacu pada hasil perhitungan analisis varians hasil belajar berupa kemampuan motorik dasar sebagai instructional effect diperoleh hasil pendekatan terpadu memberikan hasil yang lebih baik dengan rerata skor 57,15 dibandingkan dengan pendekatan konvensional dengan rerata skor 46,84. Berdasarkan hasil perhitungan ternyata $Q$ hitung $(11,72)$ lebih besar dari Q tabel $(3,79)$, kesimpulan terdapat perbedaan yang signifikan antara pendekatan pembelajaran terpadu dan pendekatan konvensional bagi siswa yang memiliki kemampuan awal berhitung dasar tinggi.

Tabel 1. Rangkuman Hasil Perhitungan Rerata dan Simpangan Baku Kemampuan Motorik

\begin{tabular}{ccc}
\hline $\begin{array}{c}\text { Kemampuan } \\
\text { Awal }\end{array}$ & $\begin{array}{c}\text { Pendekatan } \\
\text { Terpadu }\end{array}$ & $\begin{array}{c}\text { Pendekatan } \\
\text { Konvensional }\end{array}$ \\
\hline Tinggi & $\mathrm{N}=$ & $\mathrm{N}=$ \\
& 10 & 10 \\
& $\mathrm{X}=$ & $\mathrm{X}=$ \\
& 57,15 & 46,84 \\
Rendah & $\mathrm{S}=$ & $\mathrm{S}=$ \\
& 2,40 & 3,53 \\
& $\mathrm{~N}=$ & $\mathrm{N}=$ \\
& 10 & 10 \\
& $\mathrm{X}=$ & $\mathrm{X}=$ \\
Total & 52,90 & 49,97 \\
& $\mathrm{~S}=$ & $\mathrm{S}=$ \\
& 2,23 & 2,21 \\
& $\mathrm{~N}=$ & $\mathrm{N}=$ \\
& 10 & 10 \\
& $\mathrm{X}=$ & $\mathrm{X}=$ \\
& 55,02 & 48,40 \\
& $\mathrm{~S}=$ & $\mathrm{S}=$ \\
& 3,15 & 3,33 \\
\hline
\end{tabular}

Hasil Belajar Motorik Dasar Pendekatan Pembelajaran Terpadu dan Pendekatan Konvensional pada Siswa dengan Kemampuan Matematika Dasar Rendah

Mengacu pada hasil perhitungan analisis varians hasil belajar berupa kemampuan motorik dasar sebagai instructional effect diperoleh hasil pendekatan terpadu memberikan hasil dengan rerata skor 52,90 sedangkan pendekatan konvensional rerata skor 49,47. Berdasarkan hasil perhitungan ternyata $\mathrm{Q}$ hitung $(3,31)$ lebih kecil dari $\mathrm{Q}$ tabel $(3,79)$, kesimpulan tidak terdapat perbedaan yang signifikan antara pende- 
katan pembelajaran terpadu dan pendekatan konvensional bagi siswa yang memiliki kemampuan awal berhitung dasar rendah

\section{Interaksi Antara Pendekatan Pembelajaran dan Kemampuan Awal}

Mengacu pada hasil perhitungan diperoleh nilai $F_{o}(17,45)$ lebih besar dari nilai $F_{t}(4,12)$ dengan dk pembilang (a-1) (b-1) dan dk penyebut ab (n-1). Kesimpulan terdapat interaksi antara pendekatan pembelajaran penjas dengan kemampuan awal berhitung dasar.

Hasil pengujian hipotesis terangkum dalam Tabel 2.

Tabel 2. Rangkuman Hasil Perhitungan Ana-

\begin{tabular}{llrrrr}
\multicolumn{7}{c}{ va } \\
$\begin{array}{llllrl}\text { Sumber } \\
\text { Variasi }\end{array}$ & $\mathrm{dk}$ & $\mathrm{JK}$ & $\mathrm{K} T$ & $\mathrm{~F}_{\mathrm{o}}$ & $\mathrm{F}_{\mathrm{t}}$ \\
\hline Rerata & 1 & 106961,66 & 106961,66 \\
Perlakuan & 1 & & & & \\
$\mathrm{~A}$ & 1 & 438,21 & 438,21 & 56,18 & 4,12 \\
$\mathrm{~B}$ & 1 & 3,11 & 3,11 & 0,39 & 4,12 \\
$\mathrm{AB}$ & 1 & 136,14 & 136,14 & 17,45 & 4,12 \\
$\begin{array}{l}\text { Kekeliruan } \\
\text { sampling }\end{array}$ & 36 & 281,10 & 7,80 & & \\
Jumlah & 40 & & & & \\
\hline
\end{tabular}

\section{Hasil Belajar Matematika Dasar Kelompok Siswa yang Diajar Dengan Pendekatan Ter- padu dan Pendekatan Konvesional.}

Mengacu pada hasil perhitungan hasil belajar berupa kemampuan matematika sebagai nurturant effect diperoleh hasil pendekatan terpadu memberikan hasil yang lebih baik dengan rerata skor 7,20 dibandingkan dengan pendekatan konvensional dengan rerata skor 5,15. Dari hasil analisis Uji-t diperoleh harga tabel dalam taraf nyata 0,05 dengan $\mathrm{dk} 38$ dari daftar distribusi student 1,69 ternyata lebih kecil dari t-hitung $(2,65)$. Dengan demikian, dapat disimpulkan terdapat perbedaan yang signifikan antara pendekatan pembelajaran terpadu dan pendekatan pembelajaran konvensional dalam meningkatkan kemampuan matematika dasar siswa sekolah dasar

\section{Pembahasan}

Sasaran yang ingin dicapai melalui pendidikan jasmani berkaitan dengan seluruh aspek yang ada pada siswa. Betapa luas dan mendalamnya sasaran yang dicanangkan dalam pendidikan jasmani. Oleh sebab itu, mata pelajaran pendidikan jasmani disajikan berkaitan dengan tujuan yang menyeluruh, bukan hanya fisik yang jadi pusat perhatian, tapi kesejahteraan psikis merupakan unsur yang ingin dicapai turut dicapai. Tidak ada pendidikan yang lengkap tanpa kehadiran pendidikan jasmani; dan tidak ada pendidikan jasmani berkualitas tanpa kehadiran guru yang berkualitas. Kualitas guru diyakini sebagai faktor penting dalam pembelajaran pendidikan jasmani di sekolah (Maksum, 2010:1).

Pendidikan jasmani yang bermuatan pendidikan di dalamnya dimaksudkan untuk mengeliminir semua kondisi yang mengancam keleluasaan anak untuk tumbuh dan berkembang. Bahkan, diharapkan pendidikan jasmani tersebut mampu memberi peluang kepada anak untuk tumbuh secara utuh karena dari pelajaran tersebut anak dikondisikan dengan situasi-situasi yang mendukung dalam mengembangkan karakternya, menumbuhkan kepercayaan diri yang kuat, serta belajar mengembangkan wawasan intelektualnya secara meluas dan menumbuhkan rasa optimisme yang besar. Pendidikan jasmani menguntungkan terhadap kesehatan jasmani dan rohani pelakunya. Hasil penelitian Vlachopoulos dan Biddle menyimpulkan bahwa aktivitas jasmani secara personal dapat mengontrol, meningkatkan sifat emosional yang positif, dan meminimalkan dampak negatif bagi pelakunya (Sukadiyanto, 2008:230).

Oleh sebab itu, perlu kiranya dipahami materi-materi apa saja yang mungkin akan disampaikan untuk para siswa supaya sasaran yang dimaksud bisa tercapai. Salah satu kawasan yang ingin dicapai melalui pembelajaran penjas adalah kawasan motorik siswa. Kemampuan motorik siswa amat terpengaruh oleh beberapa faktor antara lain otot, syaraf dan otak. Ketiga unsur tersebut melaksanakan peranannya masing masing secara interaksi positif. Artinya, unsur unsur yang satu saling ber- 
kaitan, saling melengkapi dengan unsur lainnya untuk mencapai kondisi gerak yang sempurna. Seseorang yang memiliki derajat kemampuan gerak yang baik, diasumsikan dapat berhasil dalam menyelesaikan tugas keterampilan khusus. Winkel (1991:77). Berkaitan dengan sasaran utama pembelajaran penjas pada siswa sekolah dasar, maka keterampilan gerak tersebut terkait dengan kemampuan lari, lompat, dan lempar (Sugiyanto \& Sujarwo 1991:119-123).

Di samping ada sasaran tujuan instruksional yang harus dipenuhi oleh guru dan siswa, ada suatu sasaran yang tidak kalah penting yang akan turut tergapai dengan dengan pemberian mata pelajaran secara benar, yakni sasaran efek dampak pengiring. Setiap pembelajaran yang dilakukan hendaknya sarat dengan dampak pengiring yang akan sangat bermanfaat bagi anak. Dampak pengiring tersebut hanya akan dapat dicapai bila proses pembelajaran berlangsung dengan bermakna (Semiawan \& Joni, 1993:26). Pendidikan jasmani memberikan kesempatan aneka pengalaman belajar sebagai media untuk mendorong perkembangan, bukan saja keterampilan fisik (motorik), tetapi juga perkembangan pengetahuan dan penalaran, penghayatan nilainilai dan realisasi dalam tindakan nyata. Melalui pengelolaan pengajaran yang efektif yang berupaya untuk mencapai pengajaran secara optimal dan membangkitkan dampak pengiring sebanyak mungkin, maka sasaran pendidikan jasmani dapat tercapai. Salah satu contoh sederhana tentang dampak pengiring dalam pendidikan jasmani yakni pada saat guru memberikan materi menendang diharapkan akan dapat diraih dampak pengiring berupa peningkatan dalam bekerja sama, mengenal kemampuan, keterbatasan diri, dan sebagainya.

Sekolah adalah tempat seseorang dapat dibantu untuk mengembangkan potensi matematikanya. SD adalah tempat ideal untuk meletakkan dasar-dasar matematika. Oleh karena itu, SD harus menyiapkan program pendidikan matematika yang relevan dengan kebutuhan dan kondisi anak. Hal yang harus mendapat perhatian dari para pendidik, terutama pendidik di kelas rendah, yakni adanya kecenderungan mata pelajaran matematika bagi sebagian siswa merupakan suatu pelajaran yang cukup menakutkan dan tidak jarang bahkan jadi beban bagi para orang tua yang anaknya berada di kelas rendah (kelas 1,2 dan 3). Salah satu solusi yang ditempuh oleh sebagian orang tua untuk meringankan beban anaknya tersebut adalah dengan memasukan anak untuk mengikuti les tambahan mata pelajaran matematika.

Ada beberapa kemungkinan yang menyebabkan hal tersebut di atas, antara lain besarnya perhatian orang tua terhadap mata pelajaran ini sehingga mereka beranggapan bahwa siswa harus mampu menguasainya. Selain itu, kemungkinan lain adalah beratnya/tingginya materi berdasarkan isi kurikulum menyebabkan siswa terbebani sehingga diperlukan tambahan waktu khusus untuk meringankannya.

Mengamati karakteristik siswa pada usia sekolah dasar, yang salah satunya adalah ditandai dengan keinginan yang besar untuk bermain, diharapkan dapat membantu guru untuk menentukan suatu pendekatan pembelajaran yang tepat guna membantu mengatasi beberapa kendala yang mungkin dihadapi oleh siswa. Aktivitas bermain akan menimbulkan suasana yang gembira sekaligus akan merupakan saat yang paling tepat bagi mereka untuk menerima segala sesuatu dengan mudah. Oleh sebab itu, sangat penting bagi guru untuk selalu menjaga suasana seperti itu dalam setiap proses pembelajaran. Dari banyaknya istilah yang digunakan, tetapi tidak mengurangi hakikat dari pendekatan ini, yaitu mengadaptasi dan memodifikasi permainan agar sesuai dengan perkembangan peserta didik, "Modifying and adapting games is an important part of using this approach." (Paul, 2002:1). Terdapat tiga tahapan yang disederhanakan dalam model pendekatan ini. Sebuah model tiga tahap yang disederhanakan berfokus pada komponen pelajaran inti dari model bermain game, yaitu dimodifikasi (Dyson dkk, 2004:231). Permainan menjadi alat pendidikan yang utama untuk menuntun pertumbuhan jasmani dan rohani anak, sebab umumnya mereka bermain dalam suasana jiwa yang bebas, lepas dari segala rintangan dan tekanan. 
Pendidikan jasmani sebagaimana kita ketahui merupakan pelajaran yang sangat disukai oleh sebagian besar siswa. Suasana yang gembira dan menyenangkan ini pada gilirannya akan dapat memotivasi siswa belajar dengan sungguh-sungguh. Dalam suasana seperti itu, dapat digunakan oleh guru untuk menjadikan sesuatu yang tadinya kurang menyenangkan menjadi sesuatu yang sangat menyenangkan. Dengan demikian, bagi guru pendidikan jasmani, tanpa mengabaikan materi pelajaran pokok, dapat ikut membantu siswa dalam mata pelajaran lain, asal ada koordinasi dengan guru kelas. Seperti halnya pendidikan jasmani, mata pelajaran matematika sangat memungkinkan untuk dikaitkan dengan materi lain. Satu tujuan yang digapai melalui pembelajaran terpadu matematika dan pendidikan jasmani adalah pentingnya kesadaran ruang (spatial awareness) bagi siswa, terutama untuk mereka yang berada di kelas rendah (Coxford, 1995:147).

Hasil belajar pengembangan fisik motorik yang berkaitan dengan penelitian ini adalah selisih antara tes awal (pre test) dan tes akhir (post test) yang dilakukan siswa yang terdiri dari dua komponen, yaitu komponen kemampuan motorik dan komponen kemampuan kognitif. Komponen kemampuan motorik yang diambil datanya berupa tes lari 30 meter, tes lompat jauh tanpa awalan serta tes melempar bola kasti. Komponen kognitif yang diambil datanya adalah berupa tes kemampuan matematika dasar yang sengaja dilakukan berkaitan dengan tujuan dampak pengiring yang turut direncanakan dalam rangka pengajaran pengembangan fisik motorik .

Besarnya selisih antara tes awal dan tes akhir menunjukkan besarnya hasil belajar. Hasil Belajar ini ditunjukkan secara deskriptif, baik melalui pendekatan pembelajaran terpadu ataupun melalui pembelajaran pendekatan konvensional. Hasil pendekatan pembelajaran terpadu menunjukan hasil yang lebih baik dibanding hasil pembelajaran konvensional, baik untuk kemampuan motorik maupun untuk kemampuan kognitif (matematika dasar). Hasil penelitian ternyata secara keseluruhan antara pendekatan pembelajaran terpadu dan pendekatan pembela- jaran konvensional menunjukkan perbedaan yang berarti. Dengan tingkat kepercayaan 95\%, terdapat perbedaan yang signifikan mengenai hasil peningkatan kemampuan motorik antara pendekatan pembelajaran terpadu dengan pendekatan pembelajaran konvensional. Demikian pula terdapat perbedaan yang berarti antara pendekatan pembelajaran terpadu dengan pendekatan pembelajaran konvensional dalam hal hasil peningkatan kemampuan matematika sebagai tujuan dampak pengiring pengembangan fisik motorik yang direncanakan.

Mengacu pada kerangka berfikir serta teori yang mendukung dapat disimpulkan bahwa bagi siswa sekolah dasar, pendekatan pembelajaran terpadu sangat tepat sesuai dengan karakteristik yang dimiliki oleh siswa pada tingkat ini. Prinsip belajar sambil bermain dan belajar sambil bergembira mampu menumbuhkan usaha untuk menguasai materi dengan penuh kesungguhan yang dilakukan dengan bergembira. Melalui pendekatan pembelajaran terpadu kemauan dan keseriusan anak tampak lebih menonjol bila dibandingkan dengan pemberian materi pelajaran yang hanya dilakukan di dalam ruangan tertutup (ruang kelas). Berdasarkan pengamatan di lapangan, tampak kegembiraan dan keseriusan dalam mengikuti segala instruksi yang diberikan oleh guru mampu menjadikan suasana belajar menjadi lebih bergairah.

Pelaksanaan pendekatan permbelajaran terpadu bukanlah suatu gagasan baru dalam dunia pendidikan, khususnya pendidikan TK dan SD. Ide perlunya pelaksanaan pendekatan pembelajaran terpadu dalam proses pendidikan dan pembelajaran anak sudah dilaksanakan sejak awal abad 20. Asumsi dasarnya adalah pembelajaran terpadu merupakan salah satu strategi efektif untuk mengembangkan dan merekontruksi ilmu pengetahuan melalui interaksi dengan lingkungan dan pengalaman langsung dalam kehidupan sehari-hari. Melalui pembelajaran terpadu, anak-anak diarahkan untuk mencari dan menemukan kaitan atau hubungan antara apa yang telah mereka ketahui dengan apa yang baru bagi mereka (Saud 1996;2-3). Pendekatan pembelajaran terpadu merupakan media pem- 
belajaran yang secara efektif membantu anak untuk belajar secara terpadu dalam mencari hubungan-hubungan dan keterkaitan antara apa yang telah mereka ketahui dengan hal-hal baru atau informasi baru yang mereka temukan dalam proses belajarnya sehari-hari.

Pendekatan pembelajaran terpadu merupakan strategi pembelajaran yang efektif untuk membantu mengembangkan kemampuan anak sebagai creator and developer ilmu pengetahuan berdasarkan pengalaman nyata dalam kehidupan mereka melalui interaksinya dengan lingkungan (Beane, 1995:9). Secara singkat, dapat dirumuskan bahwa pada hakikatnya pembelajaran terpadu adalah upaya memadukan berbagai materi belajar yang berkaitan dalam satu disiplin ilmu maupun antardisiplin ilmu dengan kehidupan nyata sehingga proses belajar akan menjadi sesuatu yang bermakna dan menyenangkan anak. Ada dua hal pokok yang menjadi acuan, yakni (1) keterkaitan materi belajar antardisiplin ilmu yang relevan dengan diikat/ disatukan melalui tema pokok; dan (2) keterhubungan tema pokok tersebut dengan kehidupan dan kebutuhan nyata para siswa. Ada beberapa alasan berkenaan dengan perlunya diterapkan pembelajaran terpadu terutama bagi anak TK dan SD.

Karena anak secara alamiah berkembang secara terpadu (intelektual, fisik dan emosional), maka diperlukan proses pembelajaran yang terpadu untuk membantu perkembangan anak secara benar. Aspek intelektual, sosioemosional dan fisik anak harus dikembangkan pada waktu bersamaan. Pembelajaran terpadu merupakan suatu strategi yang memberikan kesempatan kepada anak untuk mengembangkan potensinya secara seimbang, optimal dan terpadu. Dalam realisasi pengembangan pembelajaran terpadu di Indonesia, dipilih 3 model dari model-model tersebut. Ketiga model yang dikembangan tersebut adalah connected model (model keterhubungan), thematic model (model keterhubungan bidang studi), integrated model (model terpadu/ model proyek).

Pendekatan pembelajaran konvensional adalah pendekatan yang biasa diterapkan dalam proses belajar dan melatih gerak. Dalam pen- dekatan pembelajaran konvensional, umumnya guru memakai pendekatan bidang studi, dimana setiap materi pelajaran yang diberikan pada siswa, masing-masing berdiri sendiri. Dalam pendidikan jasmani pemberian mata pelajaran dilakukan hanya berdasarkan pada isi kurikulum yang tersedia, sebagai contoh, pemberian materi melompat diberikan oleh guru dengan cara melakukan pengulangan. Cara ini menyebabkan beberapa kelemahan antara lain cepat bosan, siswa lebih banyak pasif karena menunggu giliran. Dengan demikian, proses pembelajaran tidak bisa dicapai dengan optimal.

Hasil pengamatan di beberapa sekolah menunjukan bahwa pada umumnya guru dan instruktur masih menggunakan pendekatan ini dalam proses belajar dan melatih gerak siswa di sekolah. Tujuan ideal pendidikan jasmani cukup sulit untuk dijangkau sebagai akibat dari proses pembelajaran yang terlalu menuntut anak pada kecabangan sehingga potensi anak tidak bisa berkembang secara menyeluruh. Padahal, usia sekolah dasar merupakan saat yang paling baik untuk mengembangkan siswa secara multilateral. Oleh sebab itu, kegiatan harus diberikan secara menyeluruh pula. Pendekatan pembelajaran konvensional menekankan pada penguasaan keterampilan teknik untuk meningkatkan penampilan dalam bermain, dan biasanya dilakukan secara diulang-ulang, tujuannya menekankan pada penguasaan suatu cabang olahraga. Pendekatan ini merupakan pendekatan tradisional yang pada umumnya digunakan di Indonesia, yaitu pendekatan teknik yang lebih berorientasi pada penguasaan teknik dasar kecabangan olahraga dan sering kurang memperhatikan anak secara keseluruhan serta prinsip developmentally appropriate practices (Suherman, 2011:16).

Pendekatan konvensional menghasilkan sedikit keberhasilan karena penekanan pada kinerja, pemain terampil dan memiliki teknik tidak fleksibel, dan miskin kapasitas pengambilan keputusan, kurang mandiri dalam membuat keputusan dan out come sekolah (siswa) hanya mengetahui sedikit tentang permainan. Pembelajaran pendidikan jasmani yang menekankan pada keterampilan teknik kelihatannya sangat 
membosankan bagi para siswa sebab secara sistematis setiap teknik dipelajari secara berulangulang sampai teknik tersebut dikuasai betul, baru beralih pada teknik berikutnya. Bagi para siswa, pendekatan seperti ini kurang merangsang minat dan motivasinya untuk belajar secara sungguh-sungguh yang berdampak terhadap hasil pembelajaran dan tidak meningkatkan kemampuan siswa dalam permainan. Sebab, penekanan pembelajaran yang difokuskan pada penguasaan unsur-unsur teknik dasar secara terpisah-pisah, tidak memberikan inspirasi kepada siswa untuk mampu menerapkan dalam permainan yang sebenarnya serta kurang membina dan mengembangkan daya nalar siswa tentang permainan secara utuh (Tarigan, 2001:4).

\section{PENUTUP}

Hasil peningkatan belajar motorik dasar (instruktusional effect) melalui penerapan model pendekatan pembelajaran terpadu di sekolah dasar menunjukkan hasil peningkatan yang signifikan. Rerata hasil peningkatan kemampuan motorik melalui pendekatan pembelajaran terpadu lebih besar dibandingkan rata-rata hasil peningkatan motorik melalui pendekatan pembalajaran konvensional. Hasil peningkatan belajar matematika dasar (nurturant effect) melalui penerapan model pendekatan pembelajaran terpadu dalam pengembangan kemampuan kognitif di sekolah dasar menunjukkan hasil yang signifikan. Rerata hasil peningkatan kemampuan matematika dasar melalui pendekatan pembelajaran terpadu lebih besar dibandingkan dengan rata-rata hasil peningkatan kemampuan matematika dasar melalui pendekatan pembelajaran konvensional. Terdapat perbedaan peningkatan hasil belajar motorik dasar maupun matematika dasar antara siswa yang diajar dengan pendekatan pembelajaran terpadu dengan siswa yang diajar dengan pendekatan pembelajaran konvensional. Dengan kata lain, dapat disimpulkan bahwa pendekatan pembelajaran terpadu memberikan hasil yang lebih baik dibandingkan pendekatan pembelajaran konvensional.

\section{UCAPAN TERIMA KASIH}

Penulis mengucapkan terima kasih kepada semua pihak yang telah memberikan dukungan, baik moril maupun materil, terutama Dr. H. Yudha M Saputra, Dr. H Boyke Mulyana, pimpinan Fakultas Pendidikan Olahraga dan Kesehatan UPI, serta mahasiswa yang telah membantu dalam proses pengambilan data. Ucapan terima kasih juga disampaikan kepada Redaksi Jurnal Cakrawala Pendidikan yang telah memberikan kesempatan kepada penulis untuk memublikasikan artikel ini.

\section{DAFTAR PUSTAKA}

Beane, J.A. 1995. Toward a Coherent Curriculum. Alexandria, the ASCD Yearsbook Alexandria, VA: Association of Supervision and Curriculum Development.

Coxford, F.A. 1995. Connecting Mathematic Across The Curriculum. Virginia: The National Council of Teachers of Mathematic Inc.

Dyson, B.L, Griffin, and Hastie P. 2004. Sport Education, Tactical Games, and Cooperative Leraning: Theoretical and Pedagogical Considerations.

Fraenkel JR, Wallen NE, Hyun HH. 2011. How to Design and Evaluate Research in Education. Edisi ke 8.New York. Library of Congress Cataloging-in-Publication Data, Mc. Graw Hill.

Maksum. 2010. Kualitas Guru Pendidikan Jasmani di Sekolah : Antara Harapan dan Kenyataan. Tersedia: http://www.scribd.com/doc/27098795/21.

Paul, W, et.al. 2002. Teaching Games for Understanding (TGfU) in Primary and Secondary Physical Education. Fakulty of Education. University of Wollongong, NSW.2522 Australia.

Rusman. 2011. Model-Model Pembelajaran Mengembangkan Profesionalisme Guru. 
Seri Manajemen Bermutu. Jakarta: PT Raja Grafindo Persada.

Saud, U., 1996, Pembelajaran Terpadu di Sekolah Dasar: Konsep dan Model-model Implementasinya. Bandung: Institut Keguruan dan Ilmu Pendidikan.

Semiawan C., \& Joni TR. 1993. Pendekatan Pembelajaran Acuan Konseptual Pengelolaan Kegiatan Belajar Mengajar di Sekolah. Jakarta.

Sugiyanto dan Sujarwo. 1991. Perkembangan dan Belajar Gerak. Jakarta: Departemen Pendidikan dan Kebudayaan.

Suherman A. 2011. Realitas Kurikulum Pendidikan Jasmani: Upaya Menuju Kurikulum Berbasis Penelitian. Bandung: Rizki Press.

Sukadiyanto. 2008. Peran Mata Kuliah Pendidikan Jasmani di Perguruan Tinggi. Pendidikan Kepelatihan Fakultas Ilmu Ke- olahragaan Univeristas Negeri Yogyakarta. Tersedia : http//isjd.pdii.lipi.go.id/admin/jurnal/27308304318.

Tarigan B. 2001. Pendekatan Keterampilan Taktis dalam Pembelajaran Sepak Bola. Konsep dan Metode. Depdiknas Dirjen Dikdasmen.

Tinning. 2010. Pedagogy and Human Movement. Theory, Practice, Research. London and New York: Routledge Taylor \& Francis Group.

Winkel, WS. 1991. Psikologi Pengajaran. Jakarta. PT Gramedia Indonesia.

Zuriah. 2006. Metodologi Penelitian Sosial dan Pendidikan Teori - Aplikasi. Jakarta: Penerbit. PT. Bumi Raya. 